\title{
The Cause of Acetoin Production by myo-Inositol Deficient Saccharomyces carlsbergensis
}

\author{
Takako Tomita, Tatsuo Ozawa \\ AND IsAo TOMITA \\ Shizuoka College of Pharmaceutical Sciences \\ 160 Oshika, Shizuoka (Post No. 420)
}

(Received December 12, 1968)

\begin{abstract}
For elucidating the mechanism of acetoin accumulation by myoinositol deficient Saccharomyces carlsbergensis the change of glucose concentration and $\mathrm{pH}$ during cultivation, stability of formed acetoin, the rate of acetoin synthesis and glucose uptake by resting cells were compared between normal and myo-inositol deficient yeast.

The consumption of glucose by the yeast was complete in 24 hours when myo-inositol was present in the medium, whereas $3 / 5$ still remained in the same period of incubation and a half remained unconsumed when myo-inositol was absent. $\mathrm{pH}$ change of the medium during the cultivation was insignificant for influencing acetoin accumulation.

The cell suspensions decomposed no acetoin by 7.5 -hour incubation and $30-40 \%$ by 10 -hour incubation without notable difference between normal and myo-inositol deficient cells.

myo-Inositol deficient yeast cell suspensions produced about 6.7 times acetoin ( $200 \mathrm{~m} \mu$ moles $/ \mathrm{mg}$ of dry cell weight $/ \mathrm{hr}$ ) of that by normal cell suspensions $(30 \mathrm{~m} \mu$ moles $/ \mathrm{mg}$ of $\mathrm{dry}$ cell weight $/ \mathrm{hr})$ with glucose as substrate. The external addition of myo-inositol to the reaction mixture did not decrease the acetoin production.

Glucose uptake by the deficient cells was slightly larger than that by nomal cells. Therefore, the problems such as the difference in glucose transport and the catabolism of the formed acetoin would be ruled out the from causes of the acetoin accumuation due to myo-inositol deficiency.
\end{abstract}

The accumulation of acetoin in the medium during aerobic cultivation of Saccharomyces carlsbergensis 4228 (ATCC 9080) has been regarded as one of specific symptoms of myo-inositol deficiency $(1,2)$. The amounts of acetoin released by the deficient yeast, however, depend largely on the medium carbon sources used,

1 The Role of myo-Inositol in Metabolic Control. IV. Part II : T. Tomita, T. Ozawa and I. Tomita: Chem. Pharm. Bull., in press (1969).

2 富田多嘉子, 小沢樹夫, 富田 勲. 
and 6.5-7.5 $\mu$ moles of acetoin per mg of dry cell weight accumulated in 48 hours in a glucose, fructose, mannose or sucrose medium, while only $0.04 \mu$ mole of acetoin per mg of dry cell weight was produced in a galactose medium.

The depression of respiration rate accompanying the increase in fermetation rate, so-called Crabtree effect (3), is another typical phenomenon due to myo-inositol deficiency (4). This effect was only observed when the former three sugars were used, but not in a galactose medium. A close correlation was found to exist between acetoin formation, and respiratory and growth inhibition by myo-inositol deficiency in various sugar media (2).

Polakis et al. (3) have reported that the use of high concentration of glucose in medium repressed the synthesis of respiratory enzymes in Saccharmyces cerevisiae. If the uptake of sugars (glucose particularly) and its consumption by the yeast could be decreased by myo-inositol deficiency, glucose remaining in the medium would repress the respiration and increase acetoin accumulation. Furthermore, the questions arise from the side of acetoin. Since acetoin is known to be reduced to 2,3-butylene glycol for further utilization in yeast, the effect of myo-inositol on the metabolism of acetoin should be studied especially at the time when all glucose in medium was used up. The present communication deals with the effect of myoinositol on the consumption of glucose in the medium, acetoin formation and its metabolism, and also glucose uptake by the cell suspensions of Saccharomyces carlsbergensis so that complications arrising from the constituents of culture medium may be excluded.

\section{MethodS AND Materials}

\section{Organisms}

The maintenance and the inoculation of Saccharomyces carlsbergensis strain 4228 (ATCC 9080), and the composition of the medium employed were described in the previous paper. Erlenmeyer flasks, $250 \mathrm{ml}$, containing $125 \mathrm{ml}$ of the medium for larger scale cultivation and $50 \mathrm{ml}$ flasks containing $25 \mathrm{ml}$ of the medium for smaller scale were used. Cells for the following experiments were all harvested at 24 hours from the complete or myo-inositol depleted medium and washed three times with water before use.

\section{Analysis of Culture Medium}

Upon removal of the cells by centrifugation, the amounts of acetoin in supernatant culture medium were determined by the method of Westerfeld (5) and those of glucose remaining in the medium were determined according to the direction of Glucomesser, a glucose test kit containing glucose oxidase preparation. Aliquots of samples were withdrown aseptically from cultures for the analysis of periodical changes of the compositions during cultivation.

\section{Acetoin Degradation by the Yeast Cell Suspensions}

Cell suspensions were prepared by suspending $2.4 \mathrm{mg}$ of normal or myo-inositol deficient cells (dry weight) in $1 \mathrm{ml}$ of $0.2 \mathrm{M}$ phosphate buffer ( $\mathrm{pH} \mathrm{5.0)}$. The test for acetoin degradation by the cell suspensions was started by mixing $10 \mathrm{ml}$ of the cell suspension in a $50 \mathrm{ml}$ Erlenmyer flask with $10 \mathrm{ml}$ of preincubated acetoin solution containing $4 \mu \mathrm{moles}$ in a incubater. The flasks were incubated at $30^{\circ}$ with shaking. 
Three milliliters of the samples were taken out of each reaction mixture at $0,2.5$, 5.0, 7.5, and 10 hours for the measurement of the remaining acetoin. For the control experiment $10 \mathrm{ml}$ of the acetoin solution was incubated likewise with $10 \mathrm{ml}$ of the phosphate buffer alone without cells. The amount of the cells in the reaction mixture (1.2 $\mathrm{mg}$ of dry cell weight per $\mathrm{ml}$ ) was adjusted to be equivalent to the amount in the 24-hour depleted culture, and the concentration of acetoin $(0.2$ $\mu$ mole $/ \mathrm{ml}$ ) to that in the 24 -hour complete culture medium.

\section{The Rate of Acetoin Formation by Normal or Deficient Cells}

The experiment on acetoin formation were made with $24 \mathrm{mg}$ of cells (dry weight) of both types. The cells were suspended in $1 \mathrm{ml}$ of water, and incubated with $2 \mathrm{ml}$ of $M$ glucose or sodium pyruvate solution as the substrate and $17 \mathrm{ml}$ of $0.1 \mathrm{M}$ phosphate buffer $(\mathrm{pH} 5.0)$ at $30^{\circ}$ with shaking. The amount of acetoin produced was measured on the samples which were withdrown at $0,1,2$, and 3 hours from reaction mixtures. For the purpose of recovery from myo-inositol deficiency the inositol $(500 \mu \mathrm{g})$ was added to the reaction system containing deficient cells at the same concentration as the complete medium.

\section{Glucose Uptake by Normal and Deficient Yeast Cell Suspensions}

The procedure used is essentially the same as that of Cirillo (6). The cell suspension was prepared by adding $15 \mathrm{mg}$ of cells to $1 \mathrm{ml}$ of $2 \times 10^{-3} \mathrm{M}$ iodoacetic acid (IAA) to inhibit further metabolism of glucose after the adsorption. The experiment of glucose uptake was started by adding $6 \mathrm{ml}$ of preincubated $10 \%$ glucose to $6 \mathrm{ml}$ of the cell suspensions in $50 \mathrm{ml}$ Erlenmyer flasks and carried out at $30^{\circ}$ with shaking. Three milliliter aliquots were pipetted out from the reaction mixtures at 0,30 and 60 minutes, and immediately submitted to refrigerated centrifugation at $4^{\circ}$. The cells thus obtained were washed by repeated centrifugation with three $5 \mathrm{ml}$ portions of ice cold $0.9 \% \mathrm{NaCl}$ containing $10^{-3} M$ IAA as quickly as possible. The washed cells were then extracted with $3 \mathrm{ml}$ of water in a boiling water bath for 20 minutes with marbles atop test tubes. The amounts of glucose taken up in the cells were analyzed by the method of Somogyi (7). The change of glucose uptake was examined by adding $300 \mu \mathrm{g}$ of myo-inositol to the reaction system.

\section{Materials}

Acid casein hydrolysate was obtained from Nissui Chemicals and Glucomesser for glucose analysis from Teikoku Zoki Co, Ltd, Tokyo.

\section{Results}

\section{The Change of Composition in Culture Medium}

As shown in Fig. 1, the growth of the deficient yeast was depressed to one-third that of normal yeast in 24 hours and no further increase of the growth was observed afterwards with the deficient culture. Acetoin level in the depleted culture medium steadily increased to about $5 \mu$ moles acetoin per mg of dry cell weight in this experiment, whereas that in the complete culture medium remained low during the experimental period (Fig. 2). The range of $\mathrm{pH}$ change shown in Fig. I would not be so significant to effect the acetoin level (2). The concentration of 


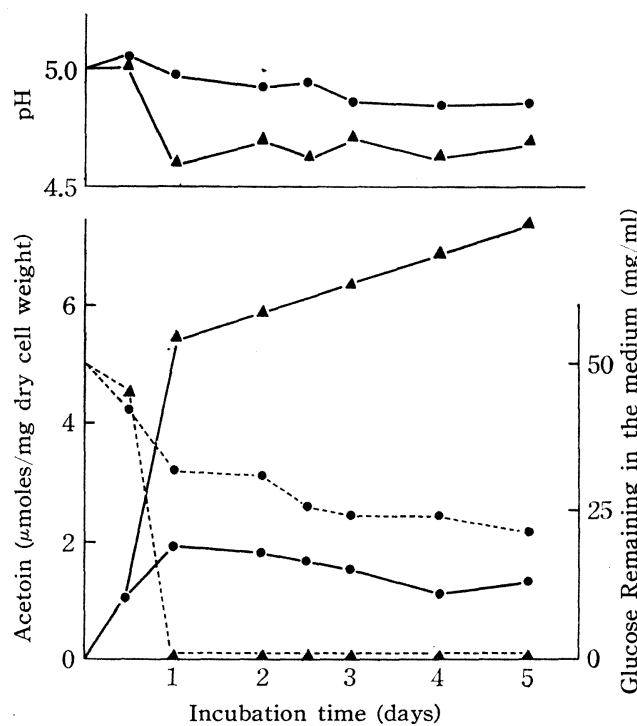

FIG. 1 The Rates of Growth and Glucose Consumption of Saccharomyces carlsbergensis Grown on Complete and myo-Inositol Depleted Media

The dashed lines indicate the growsh rate and the broken lines the amount of glucose remaining in the culture medium.

$\boldsymbol{\Lambda}$, normal culture; $\bullet$, deficient culture.

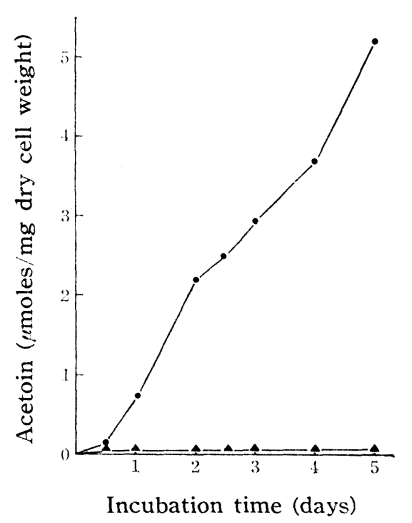

FIG. 2 Acetoin Accumulated in the Culture Media of Saccharomyces carlsber. gensis Grown with or without myo-Inositol $\Delta$, normal culture; $\bullet$, deficient culture.

glucose in the culture medium which is known as one of the most important factors in controling respiration was enzymatically determined by Glucomesser. The broken lines of Fig. 1 shows the amounts of glucose remaining in the culture media. Glucose added to the medium was completely consumed by normal yeast cells in 24 hours, while only one-third of the added glucose was consumed by the deficient cells during the same period of cultivation and a half remained unconsumed.

\section{Acetoin Degradation by Cell Suspensions}

Whether acetoin in culture medium is further metabolized or not, and whether the difference in degradation rate exists between normal and deficient cells are important to explain the difference of apparent acetoin accumulation in toth media.

TABLE 1

The Stability of Acetoin in Incubation with the Cell Suspensions of Normal or myo-Inositol Deficient Saccharomyces carlsbergensis

\begin{tabular}{|c|c|c|c|c|c|c|}
\hline \multirow{2}{*}{\multicolumn{2}{|c|}{ Type of cells }} & \multicolumn{5}{|c|}{ Incubation time $(\mathrm{hr})$} \\
\hline & & 0 & 2.5 & 5.0 & 7.5 & 10 \\
\hline \multirow{5}{*}{$\begin{array}{l}\text { Normal } \\
\text { cells }\end{array}$} & & \multicolumn{5}{|c|}{ Acetoin recovered ( $\mu$ moles $/$ flask) } \\
\hline & Exp. 1 & 4.0 & 4.0 & 4.0 & 4.2 & 2.5 \\
\hline & Exp. 2 & 4.0 & 4.2 & 4.0 & 3.8 & 2.5 \\
\hline & Average & 4.0 & 4.1 & 4.0 & 4.0 & 2.46 \\
\hline & Recovery (\%) & 100.0 & 102.5 & 100.0 & 100.0 & 61.5 \\
\hline \multirow{4}{*}{$\begin{array}{l}\text { Deficient } \\
\text { cells }\end{array}$} & Exp. 1 & 4.0 & 3.8 & 3.8 & 3.8 & 2.8 \\
\hline & Exp. 2 & 4.0 & 4.2 & 4.2 & 3.8 & 2.7 \\
\hline & Average & 4.0 & 4.0 & 4.0 & 3.8 & 2.73 \\
\hline & Recovery $(\%)$ & 100.0 & 100.0 & 100.0 & 95.0 & 68.3 \\
\hline
\end{tabular}


The consumption of acetoin was followed by incubating acetoin ( $4 \mu$ moles) with $24 \mathrm{mg}$ (dry weight) of normal or deficient cells suspended in $0.2 M$ phosphate buffer ( $\mathrm{pH} 5.0$ ) at $30^{\circ}$ with shaking. Both types of suspensions did not consume acetoin in 7.5 hours, but in 10 hours $38.5 \%$ of the acetoin was consumed by normal cells and $31.7 \%$ by the deficient cells (Table 1 ).

The difference in consumption of acetoin by $6.8 \%$ between the two types of cells would not be sufficient to explain the great difference in the acetoin level of both culture media. The result indicates that the difference of acetoin levels between complete and depleted culture media would not be the result of the difference in catabolizing abilities of the acetoin formed but the difference in acetoin synthesizing rates between the two types of cells.

\section{Comparison of Acetoin Formation Rates by Normal and Deficient Cell Suspensions}

In order to know the acetoin forming abilities of both cells excluding any factors in culture medium which might influence the amount of acetoin, both types of cells were separately incubated with glucose or sodium pyruvate as the substrate at $30^{\circ}$ with shaking.

With glucose as the substrate, normal cells produced $30 \mathrm{~m} \mu$ moles acetoin per mg of dry cell weight per hour, while the deficient cells produced $200 \mathrm{~m} \mu$ moles per mg of dry cell weight per hour which was 6.7 times that by of former cells. External addition of the inositol to the deficient yeast cell suspensions up to the concentration equivalent to that in the complete medium did not decrease the forma-

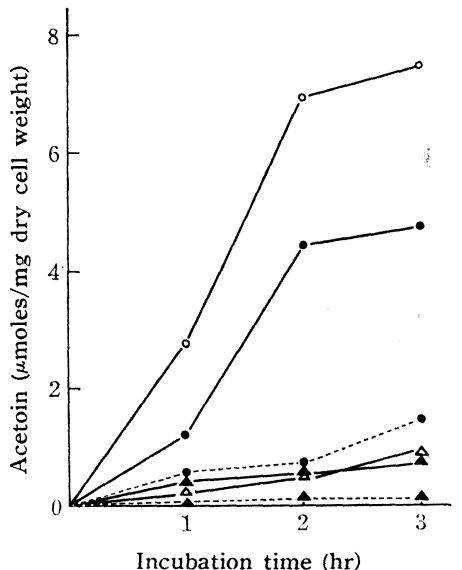

FIG. 3 The Rate of Acetoin Formation by Normal and myo-Inositol Dificient Saccharomyces carlsbergensis

Dashed lines show the acetoin formation rate with glucose as substrate, and broken lines that with sodium pyruvate as substrate. $\Delta$, normal cells; $\Delta$, myo-Inositol added to the reaction system of normal cells; $\bullet$, deficient cells; $\bigcirc$, myo-Inositol added to the reaction system of the deficient cells. tion of acetoin down to the level by normal cells, but reversely increased the acetoin formation rate up to $252 \mathrm{~m} \mu$ moles per $\mathrm{mg}$ of dry cell weight per hour. The rate increase of acetoin formation by the addition was not observed in normal cells. With sodium pyruvate as substrate, the rate of acetoin formation by both types of cells were much lower than that with glucose, though the rate by the deficient cells $(46.3 \mathrm{~m} \mu$ moles acetoin per mg per hr) was still 8 times of that by normal cells $(5.7 \mathrm{~m} \mu$ moles per $\mathrm{mg}$ per hr).

An addition of thiamine pyrophosphate $\left(2 \times 10^{-4} M\right)$ and $\mathrm{MgSO}_{4}\left(2 \times 10^{-3} M\right)$ to this reaction system as cofactors of pyruvate decarboxylase did not change the rates. Acetoin was not formed by the cells without addition of the substrate.

4. The Comparison of Glucose Uptake by Normal and Deficient Cells

The amounts of glucose taken up by normal and deficient yeast cells were 
TABLE 2

The Glucose Uptake by Normal and myo-Inositol Deficient Saccharomyces carlsbergensis

\begin{tabular}{|c|c|c|c|c|}
\hline \multirow{2}{*}{ Type of cell } & \multirow{2}{*}{$\begin{array}{l}\text { myo-Inositol added } \\
\text { to reaction mixture }\end{array}$} & & \multicolumn{2}{|c|}{ Glucose uptake in } \\
\hline & & & $30 \mathrm{~min}$ & $60 \mathrm{~min}$ \\
\hline & & \multicolumn{3}{|c|}{$10^{-7}$ moles $/ \mathrm{mg}$ dry cell weight } \\
\hline Normal & None & $\begin{array}{l}\text { Exp. } 1 . \\
\text { Exp. } 2 . \\
\text { Average }\end{array}$ & $\begin{array}{l}3.47 \\
2.97 \\
\mathbf{3 . 2 2}\end{array}$ & $\begin{array}{l}4.00 \\
4.27 \\
\mathbf{4 . 1 4}\end{array}$ \\
\hline Normal & $300 \mu \mathrm{g} / 12 \mathrm{ml}$ & $\begin{array}{l}\text { Exp. } 1 . \\
\text { Exp. } 2 . \\
\text { Average }\end{array}$ & $\begin{array}{l}3.83 \\
3.20 \\
\mathbf{3 . 5 2}\end{array}$ & $\begin{array}{l}4.18 \\
4.36 \\
\mathbf{4 . 2 7}\end{array}$ \\
\hline Deficient & None & $\begin{array}{l}\text { Exp. } 1 . \\
\text { Exp. } 2 . \\
\text { Average }\end{array}$ & $\begin{array}{l}5.18 \\
4.30 \\
\mathbf{4 . 7 4}\end{array}$ & $\begin{array}{l}6.44 \\
6.56 \\
\mathbf{6 . 5 0}\end{array}$ \\
\hline Deficient & $300 \mu \mathrm{g} / 12 \mathrm{ml}$ & $\begin{array}{l}\text { Exp. } 1 . \\
\text { Exp. } 2 . \\
\text { Average }\end{array}$ & $\begin{array}{l}6.98 \\
5.66 \\
\mathbf{6 . 3 2}\end{array}$ & $\begin{array}{l}6.96 \\
6.96 \\
\mathbf{6 . 9 6}\end{array}$ \\
\hline
\end{tabular}

measured in the presence of IAA to exclude complicated problems resulting from catabolism of glucose. The data of glucose uptake is given in Table 2.

The amount of glucose taken up by the deficient cells was larger than that of normal cells by $50 \%$ in the average, and an addition of inositol to the reaction system could not bring the deficient cells to behave like normal cells but caused further increase by $33 \%$ in glucose uptake.

\section{Discussion}

Polakis et al. (3) have reported that the development of mitochondrial system of yeast during aerobic cultivation is repressed by higher concentration of glucose in the medium and that the respiration and the related enzyme activities varied inversely with the concentration of glucose in the medium.

As shown in Fig. 1, the consumption of glucose in the medium was slow and incomplete in the deficient yeast, while it was complete in 24 hours in normal yeast. Glucose remaining for longer period of time in the cultivation of the deficient yeast could thus repress the respiration and accumulate more acetoin. The repression of respiration in the yeast grown on galactose, on the contrary, has not been observed so that the difference of galactose consumption in the medium, if any, would not give any difference on the respiration and acetoin formation.

The participation of the inositol in the form of inositol phosphatide in membrane transport has been suggested (8). The effect of the addition of the inositol on glucose uptake (33\% increase) was clear in the experiment with cell suspension. This increase of glucose consumption will probably explain the increased production of acetoin (83\% more) upon addition of the inositol to the deficient yeast cell suspension.

The utilization of acetoin, once released into the culture medium, by the yeast is another problem to be investigated. The assimilation of acetoin was assumed 
to occur faster in normal yeast which consumed up glucose in 24 hours and decrease the acetoin level in the medium more quickly than the deficient yeast. The results of both cell suspensions (normal and deficient), showed that $30-40 \%$ of the added acetoin (without glucose) was consumed during the incubation for 10 hours. The higher glucose consumption leading to easier adaptation for mitochondrial formation would doubtless assist faster utilization of acetoin in normal than the deficient yeast. The difference in acetoin degradation in both types of cell suspensions, however, was too small to explain the abnormal production of acetoin in the deficient yeast cell suspension. The mechanism of 6.7 -fold acetoin formation by the deficient cells will be discussed in the following communication.

\section{ACKNowledgement}

The authors express their deep gratitude to Dr. C. Kawasaki of Osaka Univesity and Dr. E. Hayashi of this college for their continuous encouragement and helpful advices.

\section{REFERENCES}

1. Lewin, L. M., J. Gen. Microbiol., 41, 215 (1965).

2. Ozawa, T., Tomita, I., and Tomita, T., Chem. Pharm. Bull., in press (1969).

3. Polakis, E. S., Bartley, W., and Meek, G. A., Biochem. J., 97, 298 (1965).

4. Ghosh, A., and Bhattacharyya, S. N., Biochim. Biophys. Act. 136, 19 (1967).

5. Westerfeld, W. W., J. Biol. Chem., 161, 495 (1945).

6. Cirillo, V.P., J. Bacteriol., 84, 485 (1962).

7. Somogyi, M., J. Biol. Chem., 195, 19 (1952).

8. Hokin, L. E., and Hokin, M. R., J. Biol. Chem., 233, 805 (1958). 